\title{
IS THE POLISH SMOG A NEW TYPE OF SMOG?
}

\section{CZY POLSKI SMOG JEST NOWYM TYPEM SMOGU?}

\begin{abstract}
In recent years, every winter we face the problem of excessive air pollution in the cities in Poland. This phenomenon is usually called smog and is associated with the concept of acidic smog of London type. However, there is a fundamental difference between the Great Smog of London known from the literature and winter smog episodes in Poland. While in 1952 in London the smog occurred at low atmospheric pressure, in foggy and windless weather conditions, in Poland smog episodes occur most often at the influx of cold, high-pressure air masses from the east in sunny weather. There are also various harmful components of smog - in London it was dust (suspended particulate matter), sulfur dioxide and carbon monoxide, while in Poland it is suspended particulate matter and polyaromatic hydrocarbons, especially benzo(a)pyrene. A common factor is the inversion of temperature in the ground level of the atmosphere. The chemical composition of the "Polish smog" is analyzed in the study justifying the need to distinguish the two types of smog described.
\end{abstract}

Keywords: air pollution, emission, air quality, low emission

\section{Introduction}

In recent years, in Poland, in autumn and winter we observe a repeated phenomenon of high mass concentrations of suspended particulate matter in the air, commonly referred to as smog. Originally the term "smog" comes from the combination of two English words smoke and fog. According to the literature data two types of smog are indicated: acidic, so-called London smog and photochemical (so-called Los Angeles type) smog. The acidic smog occurs mainly from November to January in the periods of low atmospheric pressure, weak wind, air temperature a few degrees centigrade above zero, and the inversion of temperatures in the temperate climatic zone [1-3]. Temperature inversion is a specific, atypical temperature distribution with altitude above the Earth surface, when air temperature rises with altitude, and does not decrease, as it results, among others, from the laws of thermodynamics. This phenomenon often occurs when warmer, humid air flows over the cooled ground. Vertical movements in the atmosphere are then strongly inhibited, and in the presence of light wind or in windless conditions, the concentration of pollutants near the ground raised up. High air humidity, at a relatively low temperature near the

\footnotetext{
${ }^{1}$ Faculty of Process and Environmental Engineering, Lodz University of Technology, ul. Wólczańska 175, 90-924 Łódź, Poland, phone +48 4263137 95, fax +48 63681 33, email: grzegorz.wielgosinski@p.lodz.pl, olga.szymanska@edu.p.lodz.pl

* Corresponding author: justyna.czerwinska@edu.p.lodz.pl
} 
ground (between 0 and 10 degrees centigrade), promotes the formation of fog [4]. These conditions prevailed in London in early December 1952, when as a result of a very intense smog in a few days, about 12,000 people died. The main components of London smog are acid gases emitted from combustion processes, such as sulfur dioxide $\left(\mathrm{SO}_{2}\right)$, nitrogen oxides $\left(\mathrm{NO}_{\mathrm{x}}\right)$ as the sum of oxide (NO) and nitrogen dioxide $\left(\mathrm{NO}_{2}\right)$, carbon monoxide (CO), carbon dioxide $\left(\mathrm{CO}_{2}\right)$, carbon black (elemental coal - C) and suspended particulate matter. They come from combustion processes carried out in small heating devices, where combustion conditions are far from ideal, i.e. complete combustion, and the exhaust gases are emitted to the air by low emitters. Near the ground an acid aerosol is then formed, which is toxic to people and the environment, and can cause allergies already at low concentrations.

The opposite of acid smog is photochemical smog named the Los Angeles type smog after the place where it was first observed and described. It is formed primarily in summer months, in subtropical zones, with intense sunlight and air temperature over $28-30{ }^{\circ} \mathrm{C}$ [5-7]. The formation of photochemical smog is also favored by light winds or windless weather and temperature inversion. The main components of photochemical smog include nitrogen oxides $\left(\mathrm{NO}_{\mathrm{x}}\right)$ as the sum of oxide (NO) and nitrogen dioxide $\left(\mathrm{NO}_{2}\right)$, carbon monoxide (CO), carbon dioxide $\left(\mathrm{CO}_{2}\right)$, volatile hydrocarbons and ozone $\left(\mathrm{O}_{3}\right)$. The source of these pollutants are, first of all, car exhaust fumes. These compounds are later subjected to a series of photochemical reactions during which ozone is formed, among others. Ozone is a very strong oxidant that causes lung diseases and destruction in the plant world in areas of smog and its surroundings. Another important toxic pollutant formed during photochemical smog are aldehydes, in particular formaldehyde.

The term "Polish smog" has been consistently used by the authors of this publication for 2 years [8]. It is a neologism, because until now such a concept has not been used. It was created in order to distinguish phenomena that appear more and more often in Polish cities, from the well-known acidic and photochemical smog known from the literature and repeatedly described. "Polish smog" differs above all in composition from the previously mentioned - it is composed mainly of suspended particulate matter - both PM10 and PM2.5, as well as PM1 and numerous polycyclic aromatic hydrocarbons, including benzo(a)pyrene. So, another term "dusty smog" can also be used $[9,10]$. These are pollutants typical for the combustion of solid fuels in low-efficiency furnaces, in the absence of exhaust gases treatment systems. The main cause of poor air quality in Polish cities are the so-called low emissions, i.e. emissions from domestic heating systems fired with solid fuels and these caused by car traffic, in particular by old vehicles without catalysts [11-13]. The "polis smog" phenomena frequent occurring in Poland in winter (e.g. after a period of frost and eastern circulation, the inflow of warmer polar-marine masses from the west, periods of high pressure, a lack of cloudiness and weak wind), it turns out that in many areas of the country excellent conditions for the formation of smog, especially "dusty", but sometimes acidic smog, are created as well. The most important characteristic feature of the "Polish smog" is formation under conditions of high pressure and negative air temperatures $[8,13]$. In winter, it is often associated with cloudless weather, which results in significant night drops in temperature and inversion. In addition, at low temperatures, the heat demand increases, and therefore higher emissions of pollutants from domestic heating systems. The result is dust concentration in part of the atmosphere at ground level, which many times exceeds the acceptable levels, in other words "dusty smog". An interesting fact is that most 
often it is not accompanied by exceeding the permissible concentrations of $\mathrm{SO}_{2}$ or $\mathrm{CO}$, so typical for acidic smog.

Already in 1986 [14], significant differences between fine and coarse particles were noticed. The chemical composition of PM2.5 is different from the composition of PM2.5-10, which results mainly from different sources of both fractions and their residence time in the atmosphere. PM2.5 can stay in the atmosphere for a longer period (days or even weeks) and be transported over very long distances (tens or even hundreds of kilometers). This fraction is dominated mainly by secondary particles, formed in the atmosphere as a result of the conversion of primary gaseous precursors, but its large part includes also particles originally emitted from fuel combustion processes, among others. The main mass of PM2.5 is composed of sulfates, ammonia, organic compounds, elemental carbon and metals.

In contrast to PM2.5, the time in which the fraction of particles with larger diameters, also known as coarse particles, remains in the air, is short, counted in minutes or hours. The PM2.5-10 fraction remains in the air and partially falls usually very close to the emission source. Taking into account the source of origin - the presence of PM2.5-10 fraction in the air is mainly attributed to direct emissions (primary origin) - this particulate matter consists mainly of crystalline materials such as silicon, iron, calcium, aluminum and their oxides and large salt particles, also of marine origin as well as plant debris contained in the atmosphere.

The average chemical composition of coarse and fine particles of suspended particulate matter is shown in Table 1.

Table 1

Average chemical composition of fine and coarse particles in urban (street canyon) and non-urban conditions [14]

\begin{tabular}{|c|c|c|c|c|}
\hline \multirow{3}{*}{ Component } & \multicolumn{2}{|c|}{ Urban areas } & \multicolumn{2}{|c|}{ Non-urban areas } \\
\hline & Fine particles & Coarse particles & Fine particles & Coarse particles \\
\hline & \multicolumn{4}{|c|}{$\left[\mu \mathrm{g} / \mathrm{m}^{3}\right]$} \\
\hline $\mathrm{SO}_{2}^{2-}$ & 17 & 1.1 & 12.0 & - \\
\hline $\mathrm{NO}_{3}{ }^{-}$ & 0.25 & 1.8 & 0.3 & - \\
\hline $\mathrm{NH}_{4}{ }^{+}$ & 4.3 & $<0.19$ & 2.3 & - \\
\hline $\mathrm{H}^{+}$ & 0.067 & $<0.01$ & 0.114 & - \\
\hline $\mathrm{C}$ & 7.6 & 3.3 & 3.3 & 1.3 \\
\hline $\mathrm{Al}$ & 0.095 & 1.4 & 0.020 & 0.20 \\
\hline $\mathrm{Si}$ & 0.20 & 3.8 & 0.038 & 0.59 \\
\hline $\mathrm{S}$ & - & - & 3.7 & 0.20 \\
\hline $\mathrm{Ca}$ & 0.15 & 3.1 & 0.016 & 0.32 \\
\hline $\mathrm{Fe}$ & 0.17 & 0.73 & 0.028 & 0.12 \\
\hline $\mathrm{Pb}$ & 0.48 & 0.13 & 0.097 & 0.014 \\
\hline
\end{tabular}

\section{Experimental}

In 2009 Mathews et al. carried out research aimed at determining the concentrations of ions in the air and percentage of fine (PM2.5) and coarse (PM2.5-10) particles in the mass of suspended particulate matter in the summer and winter season. The particulate matter was collected manually in the area of "urban background" in Zabrze. From PM2.5 and PM2.5-10, the components were extracted on Teflon filters with deionized water. The content of ions in the obtained aqueous extracts was determined by ion 
chromatography. Results of these tests are summarized in Tables 2 and 3 and illustrated in Figures 1 and 2.

Table 2

Concentrations of ions associated with PM2.5 in the air and their content in the mass of particulate matter on winter and summer working days and weekends in Zabrze in 2009 [15]

\begin{tabular}{|c|c|c|c|c|c|c|c|c|}
\hline \multirow{3}{*}{ Component } & \multicolumn{4}{|c|}{ Winter season } & \multicolumn{4}{c|}{ Summer season } \\
\cline { 2 - 9 } & \multicolumn{2}{|c|}{ Working days } & \multicolumn{2}{|c|}{ Days off } & \multicolumn{2}{c|}{ Working days } & \multicolumn{2}{c|}{ Days off } \\
\cline { 2 - 9 } & {$\left[\boldsymbol{\mu g} / \mathbf{m}^{3}\right]$} & {$[\mathbf{m g} / \mathbf{g}]$} & {$\left[\boldsymbol{\mu g} / \mathbf{m}^{3}\right]$} & {$[\mathbf{m g} / \mathbf{g}]$} & {$\left[\boldsymbol{\mu g} / \mathbf{m}^{3}\right]$} & {$[\mathbf{m g} / \mathbf{g}]$} & {$\left[\boldsymbol{\mu g} / \mathbf{m}^{3}\right]$} & {$[\mathbf{m g} / \mathbf{g}]$} \\
\hline $\mathrm{Na}^{+}$ & 0.39 & 5.55 & 0.5 & 9.82 & 0.22 & 13.02 & 0.25 & 12.44 \\
\hline $\mathrm{NH}_{4}{ }^{+}$ & 2.02 & 34.31 & 1.99 & 36.15 & 0.53 & 30.64 & 0.52 & 27.72 \\
\hline $\mathrm{K}^{+}$ & 0.23 & 2.7 & 0.56 & 8.27 & 0.14 & 5.64 & bld & bld \\
\hline $\mathrm{Mg}^{2+}$ & 0.14 & 1.3 & bld & bld & bld & bld & bld & bld \\
\hline $\mathrm{Ca}^{2+}$ & 0.47 & 4.2 & bld & bld & bld & bld & bld & bld \\
\hline $\mathrm{F}^{-}$ & 0.08 & 2.09 & 0.07 & 1.46 & 0.05 & 2.91 & 0.06 & 2.39 \\
\hline $\mathrm{Cl}^{-}$ & 1.54 & 19.57 & 1.51 & 24.25 & 0.03 & 1.92 & 0.04 & 2.33 \\
\hline $\mathrm{NO}_{3}{ }^{-}$ & 2.61 & 55.75 & 3.63 & 65.66 & 0.043 & 24.38 & 0.59 & 31.09 \\
\hline $\mathrm{PO}_{4}{ }^{2-}$ & bld & bld & 0.25 & 5.82 & bld & bld & bld & bld \\
\hline $\mathrm{SO}_{4}{ }^{2-}$ & 5.62 & 121.15 & 5.4 & 107.39 & 3.26 & 190.69 & 3.2 & 170.85 \\
\hline
\end{tabular}

bld - below the limit of detection

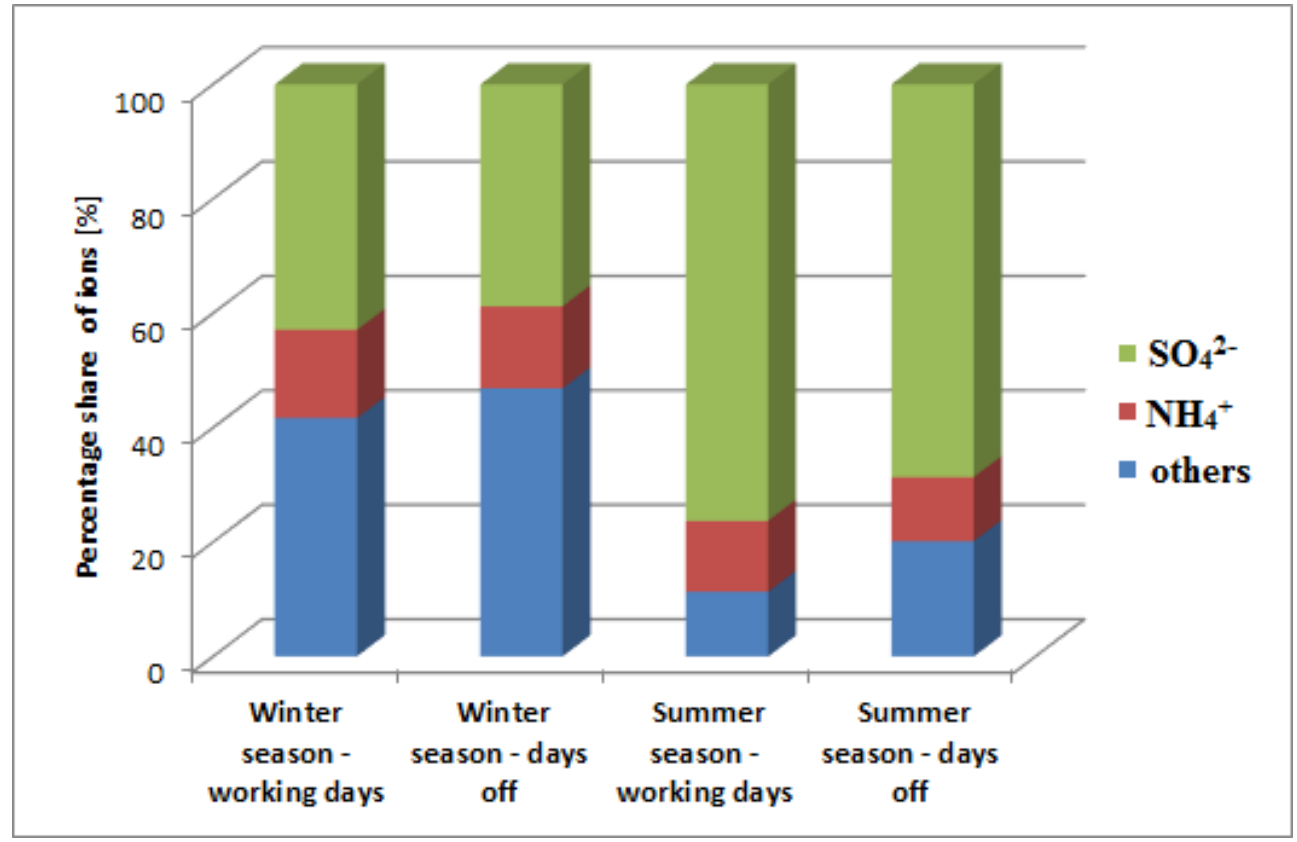

Fig. 1. Percentage of cations and anions in the total content of ions associated with fine particles on winter and summer working days and weekends in Zabrze in 2009 [15]

The concentrations of $\mathrm{Cl}^{-}$and $\mathrm{NO}_{3}{ }^{-}$in PM2.5 observed in the winter and summer seasons differ significantly. The proportions of $\mathrm{Na}^{+}, \mathrm{NH}_{4}{ }^{+}, \mathrm{K}^{+}, \mathrm{F}^{-}$and $\mathrm{SO}_{4}{ }^{2-}$ ions in the mass of particulate matter are much higher in summer than in winter. The largest share in total ion concentrations is that of $\mathrm{SO}_{4}^{-}$. In summer, sulfate ions account for almost $70 \%$ of 
the concentration of all ions in the air both on working days and weekends, while in winter it is $40 \%$. In summer part of $\mathrm{SO}_{4}^{-}$in the suspended particulate matter comes from the transformations of gaseous precursors, while in winter the concentration of this ion in the air is mainly related to primary emissions from the combustion of fossil fuels. Significant part of the concentration of total ions in the air in both periods constitute $\mathrm{NO}_{3}^{-}$and $\mathrm{Cl}^{-}$ (20-25\%). In winter, the concentration of $\mathrm{Cl}^{-}$was partly related to the combustion of fossil fuels and wood, but also to the sprinkling of roads with salt. In summer, chlorine in fine particles could have come from the combustion of wood, fuels and also transport emissions, but its contribution to the total ions was negligible. The largest share in the concentration of ions in all measurement periods had $\mathrm{SO}_{4}^{-}$(from 55 to $60 \%$ ), then $\mathrm{NO}_{3}{ }^{-}$(20-30\%). In the mass of coarse particles much lower concentrations of $\mathrm{NH}_{4}{ }^{+}$ions were also noted.

Concentrations of ions associated with PM2.5-10 in the air and their content in the mass of particulate matter on winter and summer working days and weekends in Zabrze in 2009 [15]

\begin{tabular}{|c|c|c|c|c|c|c|c|c|}
\hline \multirow{3}{*}{ Component } & \multicolumn{4}{|c|}{ Winter season } & \multicolumn{4}{c|}{ Summer season } \\
\cline { 2 - 9 } & \multicolumn{2}{|c|}{ Working days } & \multicolumn{2}{|c|}{ Days off } & \multicolumn{3}{c|}{ Working days } & \multicolumn{3}{c|}{ Days off } \\
\cline { 2 - 9 } & {$\left[\boldsymbol{\mu g} / \mathbf{m}^{3}\right]$} & {$[\mathbf{m g} / \mathbf{g}]$} & {$\left[\boldsymbol{\mu g} / \mathbf{m}^{3}\right]$} & {$[\mathbf{m g} / \mathbf{g}]$} & {$\left[\boldsymbol{\mu g} / \mathbf{m}^{3}\right]$} & {$[\mathbf{m g} / \mathbf{g}]$} & {$\left[\boldsymbol{\mu g} / \mathbf{m}^{3}\right]$} & {$[\mathbf{m g} / \mathbf{g}]$} \\
\hline $\mathrm{Na}^{+}$ & 0.31 & 44.69 & 0.11 & 8.24 & 0.21 & 14.59 & 0.15 & 17.55 \\
\hline $\mathrm{NH}_{4}{ }^{+}$ & 0.1 & 15.08 & 0.04 & 2.98 & 0.11 & 7.13 & 0.03 & 2.78 \\
\hline $\mathrm{K}^{+}$ & 0.22 & 23.18 & bld & bld & bld & bld & bld & bld \\
\hline $\mathrm{Mg}^{2+}$ & bld & bld & bld & bld & bld & bld & bld & bld \\
\hline $\mathrm{Ca}^{2+}$ & bld & bld & bld & bld & bld & bld & bld & bld \\
\hline $\mathrm{F}^{-}$ & 0.06 & 8.34 & 0.05 & 4.88 & 0.03 & 2.34 & 0.04 & 4.37 \\
\hline $\mathrm{Cl}^{-}$ & 0.18 & 23.75 & 0.11 & 9.56 & 0.08 & 4.9 & 0.08 & 9.51 \\
\hline $\mathrm{NO}_{3}{ }^{-}$ & 0.93 & 121.89 & 0.89 & 78.26 & 0.81 & 55.62 & 0.82 & 91.47 \\
\hline $\mathrm{PO}_{4}{ }^{2-}$ & 0.1 & 4.27 & bld & bld & bld & bld & bld & bld \\
\hline $\mathrm{SO}_{4}{ }^{2-}$ & 2.01 & 260.69 & 1.74 & 173.78 & 1.38 & 94.34 & 1.33 & 149.1 \\
\hline
\end{tabular}

bld - below the limit of detection

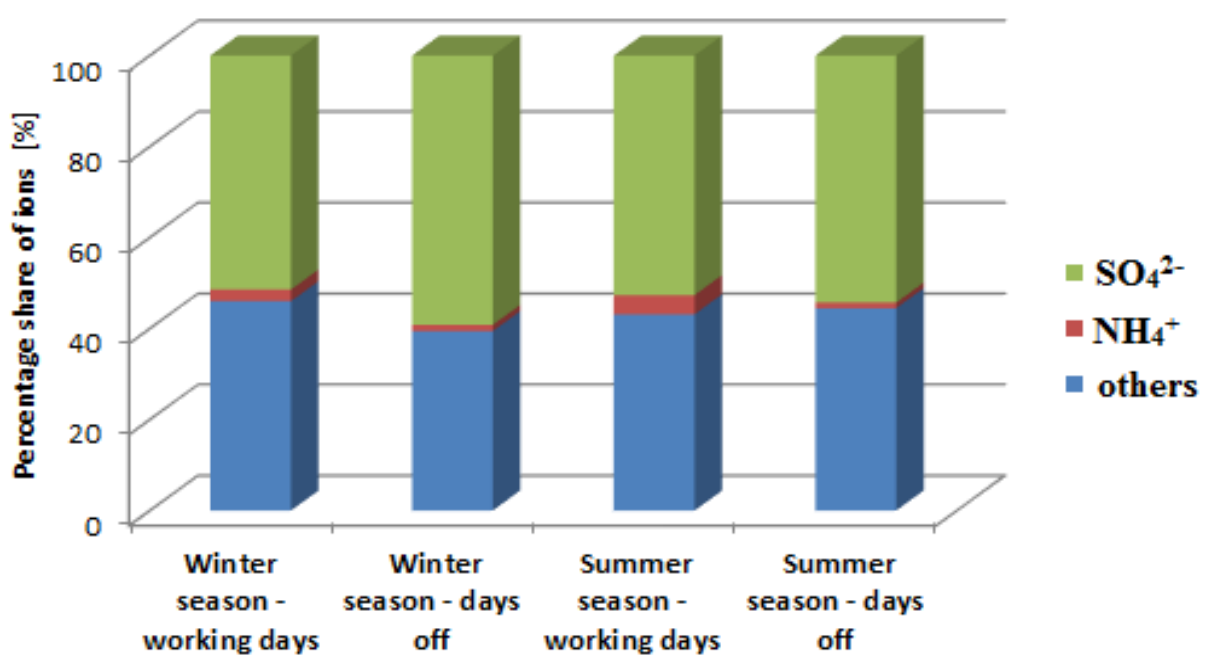

Fig. 2. Percentage of cations and anions in the total content of ions associated with coarse particles on winter and summer working days and weekends in Zabrze in 2009 [15] 
In 2012 Degorka et al. [15] conducted research on the composition of PM2.5 in various monitoring stations in Poland. In their work, they presented results of the measurements of mass concentration of PM2.5 and its chemical composition carried out at three sites: Gdansk, Katowice and Diabla Gora. The location of these stations is shown in Figure 3.

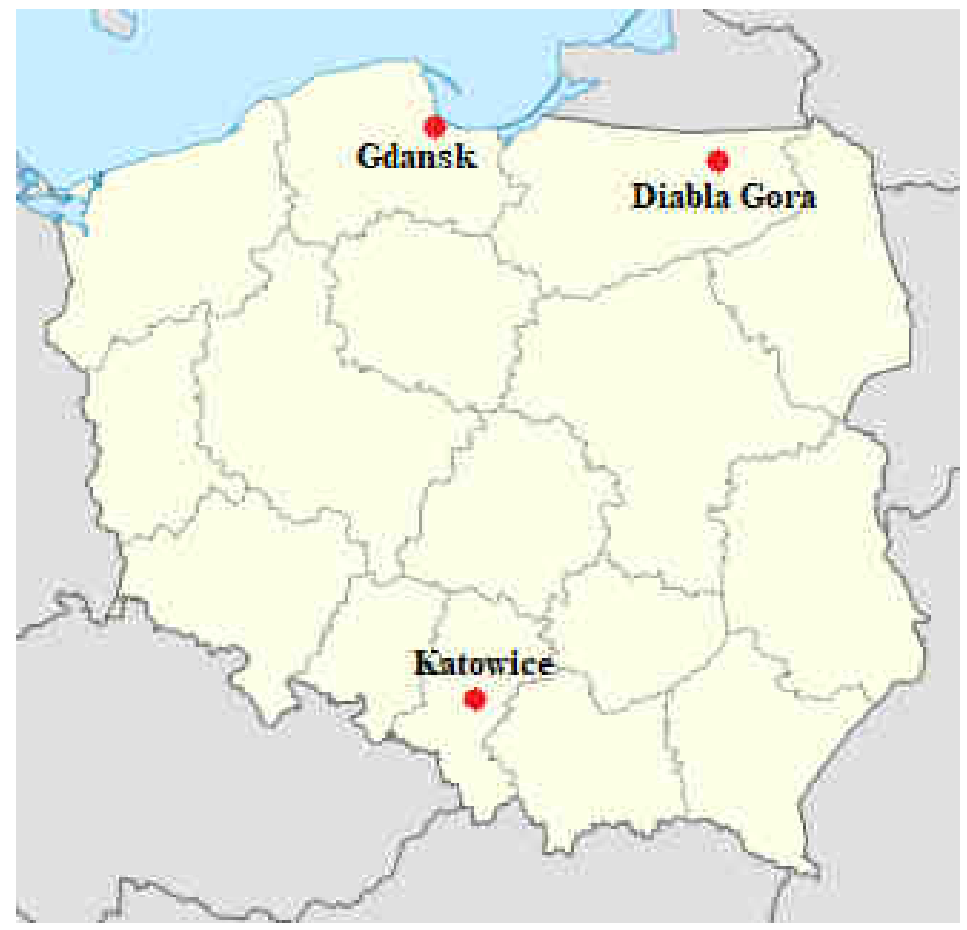

Fig. 3. Location of monitoring stations in Gdansk, Katowice and Diabla Gora

Table 4 Average annual concentrations of PM2.5 components in different seasons of 2010 in the monitoring stations in Katowice, Gdansk and Diabla Gora [16]

\begin{tabular}{|c|c|c|c|c|c|c|c|c|c|c|}
\hline & $\mathrm{SO}_{4}{ }^{2-}$ & $\mathrm{NO}_{3}$ & $\mathrm{Cl}^{-}$ & $\mathbf{N H}_{4}{ }^{+}$ & $\mathrm{Na}^{+}$ & $\mathbf{K}^{+}$ & $\mathrm{Ca}^{2+}$ & $\mathrm{Mg}^{2+}$ & others \\
\hline & & \multicolumn{9}{|c|}{$\left[\mu \mathrm{g} / \mathrm{m}^{3}\right]$} \\
\hline \multirow{4}{*}{ Katowice } & Spring & 2.81 & 2.44 & 1.23 & 2.82 & 2.78 & 0.21 & 0.68 & 0.13 & 0.33 \\
\hline & Summer & 4.41 & 0.74 & 0.79 & 0.72 & 0.48 & 0.12 & 0.24 & 0.09 & 0.36 \\
\hline & Autumn & 4.21 & 2.46 & 1.54 & 1.96 & 0.44 & 0.29 & 0.30 & 0.06 & 0.44 \\
\hline & Winter & 6.89 & 4.74 & 3.32 & 4.22 & 1.06 & 0.33 & 0.21 & 0.08 & 0.76 \\
\hline \multirow{4}{*}{ Gdansk } & Spring & 1.38 & 2.10 & 0.56 & 1.13 & 1.21 & 0.09 & 0.20 & 0.06 & 0.38 \\
\hline & Summer & 2.01 & 0.51 & 0.21 & 0.44 & 0.48 & 0.04 & 0.20 & 0.04 & 0.30 \\
\hline & Autumn & 1.87 & 1.89 & 0.47 & 0.83 & 1.78 & 0.14 & 0.21 & 0.06 & 0.16 \\
\hline & Winter & 4.30 & 5.64 & 1.22 & 3.18 & 0.85 & 0.34 & 0.14 & 0.09 & 0.20 \\
\hline \multirow{4}{*}{ Diabla Gora } & Spring & 1.53 & 1.88 & 0.14 & 1.13 & 1.55 & 0.12 & 0.12 & 0.05 & 0.11 \\
\hline & Summer & 2.12 & 0.30 & 0.19 & 0.36 & 0.75 & 0.06 & 0.06 & 0.04 & 0.16 \\
\hline & Autumn & 2.01 & 1.46 & 0.20 & 0.67 & 1.05 & 0.10 & 0.10 & 0.04 & 0.10 \\
\hline & Winter & 4.85 & 4.77 & 0.22 & 2.31 & 1.81 & 0.19 & 0.19 & 0.03 & 0.08 \\
\hline
\end{tabular}


The tests of PM2.5 carried out have shown little variation in its chemical composition. The results are evidence of its anthropogenic origin. Primary emission components dominate in the composition of this particulate matter. A significant proportion of the secondary inorganic aerosol composed of sulfates and nitrates as well as ammonium compounds was found. Results of the test are presented in Table 4 and in Figures 4-6.

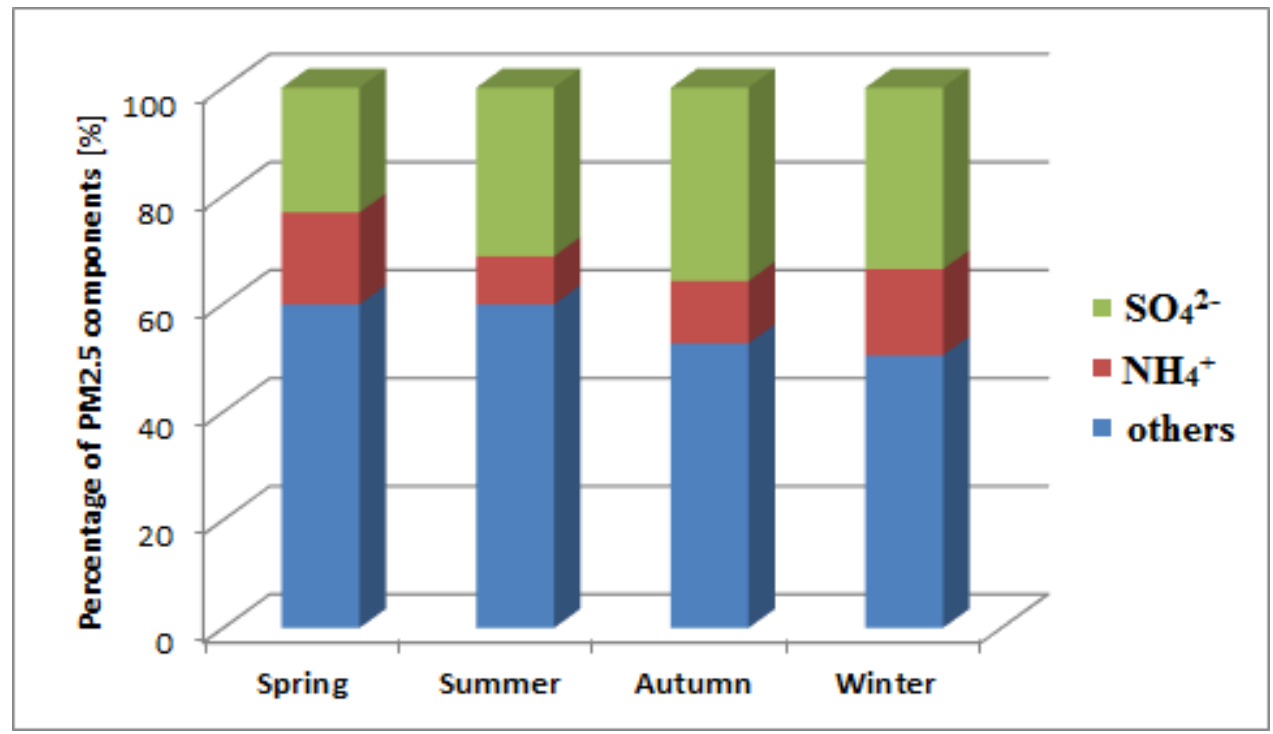

Fig. 4. Percentage of PM2.5 components in particular seasons of 2010 in the monitoring station in Diabla Gora [16]

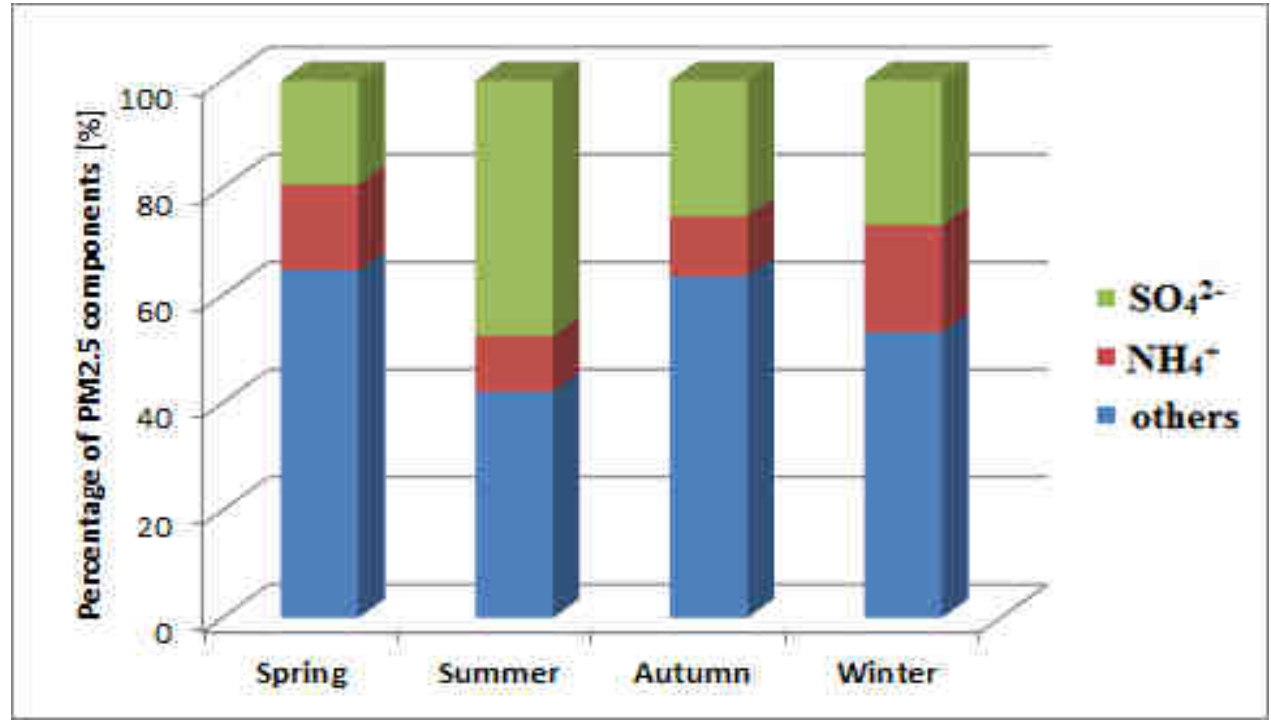

Fig. 5. Percentage of PM2.5 components in particular seasons of 2010 in the monitoring station in Gdansk [16] 
The concentration of organic and elemental carbon in PM2.5 was high in the monitoring station in Diabla Gora. Among the determined anions, sulfate ions prevailed. Among the tested anions, sulfates dominated in winter, while in summer the concentration of nitrates increased.

In the monitoring station in Gdansk, like in other stations, a dominant percentage of nitrate and sulfate ions was observed (average annual concentrations were 2.5 and $2.4 \mu \mathrm{g} / \mathrm{m}^{3}$, respectively). The station also had higher concentrations of chlorine ions.

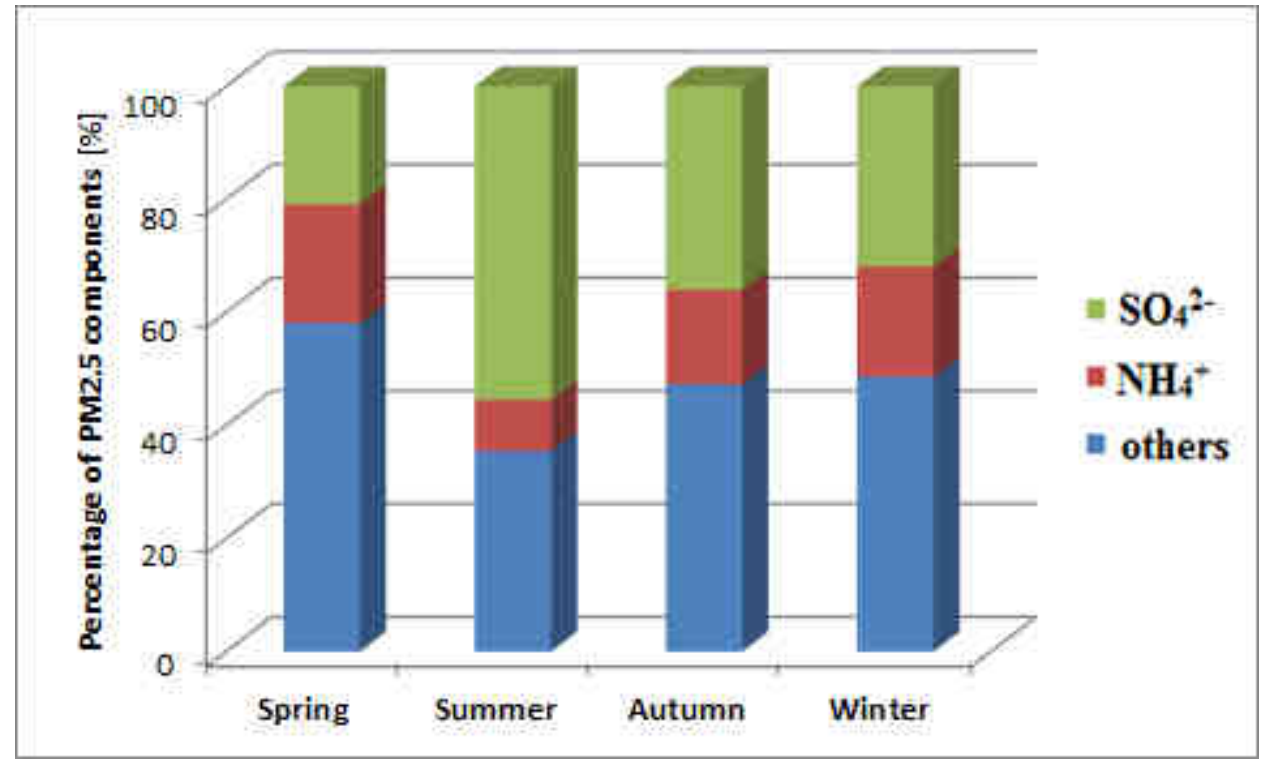

Fig. 6. Percentage of PM2.5 components in particular seasons of 2010 in the monitoring station in Katowice [16]

In the last analyzed monitoring station in Katowice, also a dominant concentration of sulfate and nitrate ions was observed (4.5 and $2.5 \mu \mathrm{g} / \mathrm{m}^{3}$, respectively). Similarly to other locations, in summer there was a significant decrease in the concentration of nitrate ions in the winter period nitrate and sulfate dominated, while in summer the content of sulfates increased significantly. Such a significant loss of nitrogen in the summer period could result from photochemical transformations of nitrogen oxides. The concentrations of nitrites in all monitoring stations were similar, which indicates their high content in the whole country. The concentration of sulfate ions in the Katowice area was twice as high as in other monitoring stations, which indicates that the energy sector could contribute significantly (secondary aerosol from the combustion of high-sulfur coal). A significant increase in the concentration of sulfates in the heating season suggests that they come from the combustion of fuels for energy purposes.

\section{Conclusions}

Every year in winter, we observe periods of high concentrations of particulate matter in Poland. In the popular language, we are talking about "smog", which is responsible for poor 
air quality in our cities. However, comparing the recorded in Poland smog episodes with the classic London smog (year 1952), it is easy to notice the difference between the "Polish smog" and London one. It appears mainly in the high-atmospheric pressure weather, with negative temperatures [8], with the inflow of cold continental air masses from Russia, while acidic smog (the so-called London type) arises in foggy weather, at low-atmospheric pressure and temperatures a little above $0{ }^{\circ} \mathrm{C}$. A common inversion of temperature that hinders the dispersion of pollutants in the atmosphere is a common feature.

There are also significant differences in the chemical composition of the registered pollutants. In Poland, the basic pollution causing exceeding the permissible concentrations of pollutants in the air is dust - PM10 and PM2.5, as well as polycyclic aromatic hydrocarbons - mainly carcinogenic benzo(a)pyrene. In the case of London smog, the most important pollutants are sulfur dioxide, suspended dust (mainly silicate dioxide), carbon monoxide and nitrogen oxides. In both cases the most important source of these pollutants are combustion processes in low-quality household (local) heating devices and partly car traffic. The aim of this work was to find an answer to the question why, if the source of pollution are solid fuel combustion processes, during smog episodes in Poland, there are no exceeded permissible concentrations of sulfur dioxide, but only PM10 and PM2.5.

On the basis of the analysis carried out in this paper, it was found that PM2.5 and PM10 in Poland mainly consist of ammonium and sulfate ions. This makes us suppose that during the combustion of coal ammonia is produced, which partially binds to the formed sulfur oxides. Polish coals most likely contain large amounts of ammonium nitrogen, which during combustion releases ammonia binding sulfur dioxide. It is known that the wood that fires fireplaces in England contains this ammonium nitrogen much less. This would explain why the permissible concentration of $\mathrm{SO}_{2}$ was not exceeded in smog episodes during which high concentrations of both PM10 and PM2.5 in Poland occurred, contrary to smog episodes in London. Research on the confirmation of this thesis is continued.

The above argument allows us to state that the so-called "Polish smog" differs qualitatively from the acidic and photochemical smog described in the literature.

\section{References}

[1] Mira-Salama D, Gruning C, Jensen NR, Cavalli P, Putaud JP, Larsen BR, et al. Atmos Res. 2008;88:294-304. DOI: 10.1016/j.atmosres.2007.11.025.

[2] Kim HS, Huh JB, Hopke PK, Holsen TM, Yi SM. Atmos Environ. 2007;41:6762-6770. DOI: 10.1016/j.atmosenv.2007.04.060.

[3] Chu SH. Atmos Environ. 2004;38:5237-5246. DOI: 10.1016/j.atmosenv.2004.01.055.

[4] Rodriguez MC, Dupont-Courtade L, Oueslati W. Renew Sust Energy Rev. 2016;53:1-9. DOI: 10.1016/j.rser.2015.07.190.

[5] Muilwijk C, Schrijvers PJC, Wuerz S, Kenjeres S. Atmos Environ. 2016;147:470-484. DOI: 10.1016/j.atmosenv.2016.10.022.

[6] Rye PJ. Math Comput Model. 1995; 21:111-117. DOI: 10.1016/0895-7177(95)00059-B.

[7] Wang X, Chen J, Cheng T, Zhang R, Wang X. J Environ Sci. 2014;26:1894-1902. DOI: 10.1016/j.jes.2014.07.003.

[8] Wielgosiński G, Czerwińska J, Namiecińska O, Cichowicz R. E3S Web Conferences. 2018;28:1-9. DOI: 10.1051/e3sconf/20182801039.

[9] Fan YV, Perry S, Klemes JJ, Lee ChT. J Clean Prod. 2018;194:673-684. DOI: 10.1016/j.jclepro.2018.05.151.

[10] Shi H, Wang Y, Chen J, Huisingh D. J Clean Prod. 2016;112:1261-1271. DOI: 10.1016/j.jclepro.2015.10.068.

[11] Dzikuć M, Adamczyk J, Piwowar A. Atmos Environ. 2017;160:1-8. DOI: 10.1016/j.atmosenv.2017.04.011.

[12] Dzikuć M. J Clean Prod. 2017;166:81-87. DOI: 10.1016/j.jclepro.2017.08.042. 
[13] Zawada M, Starostka-Patyk M. Transp Res Proc. 2016;16:587-597. DOI: 10.1016/j.trpro.2016.11.055.

[14] Finlayson-Pitts BJ, Pitts JN. Atmospheric Chemistry: Fundamentals and Experimental Techniques. New York: Wiley; 1986. ISBN 9780471882275.

[15] Mathews B, Rogula-Kozłowska W, Klejnowski K, Rogula-Kopiec P. Wybrane jony związane z PM2,5 i PM2,5-10 w Zabrzu - stężenie w powietrzu i udział w masie pyłu. Ochrona powietrza w teorii i praktyce. (Selected ions associated with PM2.5 and PM2.5-10 in Zabrze - concentration in air and share in dust mass. Air protection in theory and practice). Zabrze: Instytut Podstaw Inżynierii Środowiska Polskiej Akademii Nauk (Institute of Environmental Engineering Polish Academy of Sciences in Zabrze); 2010:T1:205-215. ISBN 9788360877487.

[16] Degórka A, Śnieżek T, Klejnowski K, Rogula-Kozłowska W, Błaszczak B, Rogula-Kopiec P, et al. Skład chemiczny pyłu PM2,5 na wybranych stacjach monitoringowych w Polsce. Ochrona powietrza w teorii i praktyce. (Chemical composition of PM2.5 dust at selected monitoring stations in Poland. Air protection in theory and practice). Zabrze: Instytut Podstaw Inżynierii Środowiska Polskiej Akademii Nauk (Institute of Environmental Engineering Polish Academy of Sciences in Zabrze); 2012:T1:13-27. ISBN 9788360877883. 